\title{
The Economical Factors Affecting Residential Property Price: The Case of Penang Island
}

\author{
Gholamreza Zandi ${ }^{1}$, Mahadevan A/L Supramaniam² ${ }^{2}$, Ayesha Aslam ${ }^{3} \&$ Lai Kin Theng ${ }^{4}$ \\ ${ }^{1}$ Graduate School of Business, SEGi University, Malaysia \\ ${ }^{2}$ Research and Innovation Management Centre, SEGi University, Malaysia \\ ${ }^{3}$ PhD Scholar, SEGi University, Malaysia \\ ${ }^{4}$ MBA Candidate, SEGi University, Malaysia \\ Correspondence: GholamReza Zandi, Associate Professor Dr., Graduate School of Business, SEGi University, \\ Kuala Lumpur, 47810, Malaysia. Tel: 60-3-6145-3148. E-mail: zandi@ segi.edu.my
}

Received: October 9, 2015

doi:10.5539/ijef.v7n12p200
Accepted: October 29, $2015 \quad$ Online Published: November 25, 2015

URL: http://dx.doi.org/10.5539/ijef.v7n12p200

\begin{abstract}
The main purpose of this study is to investigate the economical factors which are effecting on the residence property price in the specific state of Malaysia called "Penang". For this research, secondary data were collected from Bank Negara Malaysia, Department of Statistic Malaysia, Ministry of Finance Malaysia and Valuation and Property Service Department. All the economical factors are on a yearly basis from 2007 to 2014. The study was directed to verify the relationship between the economical factors and housing price in Penang. Both the individual effects and the interactive effects are analyzed. According to the analysis and calculations, the main factor Base Lending Rate (BLR) and second most effecting factor Gross Domestic Product (GDP) are the strong Factors which affect the property prices in Penang.
\end{abstract}

Keywords: economical, Penang, housing price, BLR, GDP

\section{Introduction}

Penang is considered the most developed and economically important state because of vastly urbanized and industrialized. Based on NAPIC (National Property Information Center), the average property price in Penang currently stands at RM 336,521. Penang property price is slightly higher than the national average price which recorded approximately RM300,000.

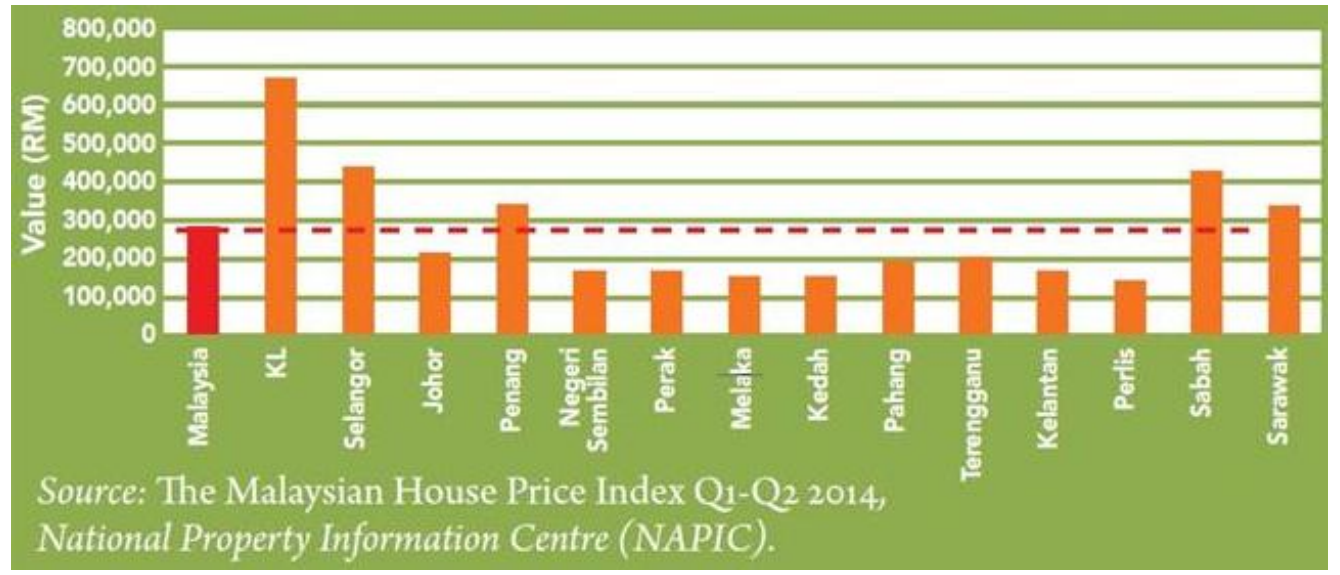

Figure 1. Average price for all types of properties as of Q2 2014

Public is concern on the potential overheated property market, especially in Penang. Department of statistics Malaysia projected that Penang population will potentially hit 1.75 million in year 2020. Malaysia Property 
Incorporated (MPI) found that potential oversupply for year 2015 is 45,000 units as the population growth rate is slower than the new supply [YK Heng, 2013].

The most densely populated district on Penang Island is in the north-east. This area includes George Town, Tanjung Tokong and Tanjung Bungah. In recent years, the hottest investment spot for big-name developers have changed to the north-west of the Island. On the mainland, more new housing is expected to launch at central Seberang Perai. The announcement of development projects in Batu Kawan, including IKEA and KDU University College and the opening of the second Penang Bridge have certainly boost up the housing development at south Seberang Jaya.

Due to the introduction of more stringent real property gain tax (RPGT) and maximum loan-to-value ratio, the number of Penang residential property transaction showed significant slowdown.

\begin{tabular}{|c|c|c|c|c|c|c|}
\hline & & 2013-03 & 2013-Q4 & 2014-Q1 & 2014-02 & 2014-03 \\
\hline \multirow{2}{*}{$\begin{array}{l}\text { Penang } \\
\text { Island }\end{array}$} & North-East & 1,787 & 1,912 & 1,559 & 1,579 & 1,577 \\
\hline & South-West & 605 & 672 & 572 & 456 & 497 \\
\hline \multirow{3}{*}{$\begin{array}{l}\text { Seberang } \\
\text { Perai }\end{array}$} & North & 597 & 655 & 652 & 860 & 647 \\
\hline & Central & 938 & 901 & 909 & 1,094 & 879 \\
\hline & South & 592 & 558 & 599 & 743 & 594 \\
\hline TOTAL & & 4,519 & 4,698 & 4,291 & 4,732 & 4,194 \\
\hline
\end{tabular}

Figure 2. Number of residential property transactions by district in Penang

Developers were concerned about the effect on the primary property market by new policies pursuant to the Budget 2014 announcement such as banning the Developer's Interest Bearing Scheme (DIBS), tightening the loan-to-value ratio and declining bridging loans to finance property developments.

Additionally, the new housing rules commenced by Penang State Government in $1^{\text {st }}$ February 2014 further impact the property transaction volumes and property price. The housing rules include low-cost and medium-cost housing rules, affordable housing rules, foreigner's property purchasing rules and additional levy charges for property sold within 3 years.

The main purpose of this study is to measure the relationship between the housing price and the economic variables such as gross domestic product rate, inflation rate, income increment rate, Bank interest rate and real property gain tax rate.

\section{Literature Review}

\subsection{Inflation Rate (INF Rate)}

Inflation is often defined as a sustained increase in prices for a broad range of goods. Economists explain that rising prices are the symptom, however, and not the cause. The cause of inflation is the devaluation of currency, frequently brought about by the introduction of more currency into the economy. Lately, there are number of papers cite the effect of inflation on housing market and prices. Piazzesi and Schneider (Piazzesi \& Schneider, 2009) pointed out that higher inflation rate tends to cause an increase in housing price. Feldstein (Feldstein, 1980) also commented that the prices of house have substantially increased more than the general price level which might indicate that the inflation rate contributed in housing price hiking. However, the study of Tan (Tan, 2011) shows that inflation rate is not a significant determinant of housing price. Dongchul Cho (2005) discusses the relationship between interest rate and inflation rate on one part and the house price relative to chonsei price (up-front lump-sum deposit from the tenant to the owner for the use of the property with no additional requirement for periodic rent payments) on the other. The key point of his paper was that the relative price of sales to chonsei depends on the ratio of inflation to real interest rate, and thus even when the monetary authority maintains a pre-announced target level of inflation rate, the relative price of sales to chonsei rises if the real interest rate is lowered. This finding seems to help understand the recent hikes of the house prices despite the stabilizing chonsei prices. Recognizing this relationship, it may be sensible to lower the target inflation rate in an 
economy where real interest rates permanently decline, if the society wishes to reduce its adverse effect on the wealth distribution between house owners and chonsei tenants.

\subsection{Gross Domestic Product Rate (GDP Rate)}

Piazzesi and Scheneider (Piazzesi \& Schneider, 2009] pointed out that the housing price has strong positive correlation with GDP rate. According to Zhu (Zhu, 2006), the housing market and housing price demonstrated a very significant positive correlation with GDP rate in Asia, especially in China and Korea. On the other side, the study of Ley and Tutchener (Ley \& Judith, 2010) shows that GDP rate has negative influence on housing price. They found that globalization has much stronger effects towards housing price movement. Ray M Valadez revealed the long standing relationship between a nation's economic footing as measured by its GDP and housing prices has been observed and studied over the past century by academicians as well as by private and public officials. His study looked at the relationship between housing and GDP before, during, and after the most climatic period of our economic time since the great depression of the 1930s. The period between the first quarter of 2005 and the end of 2009 saw dramatic changes in the behavior of financial and economic markets. Global financial markets came to a halt and global free market economies fell to their knees. Could housing have such dramatic effects on the economy of a nation? This question was examined in his study. Then the literature review along with the results of this study's correlation analysis provides convincing evidence that a strong relationship exists between the two variables. However, to establish a scientific causal effect will be a challenge because managing control groups in this arena is impossible. Trey Garrison (2015) did research on how housing market corrections drag on GDP. The research examined economic developments in countries after housing market declines. "On average, GDP is around $6 \%$ lower than its pre-price peak path after a price correction in the housing market, although there is considerable variation," said Ruosha $\mathrm{Li}$, an analyst in Moody's Macro Financial Analysis team. "Our research showed that for a given fall in house prices the average GDP shortfall is larger in advanced economies than in emerging markets." For every $10 \%$ decline in house prices (in real terms), GDP falls by around 4\% from its pre-peak path, according to the study of 50 global episodes of housing market corrections since 1973. Property price downturns since 2006 have been linked to a larger fall in GDP. The GDP gap between pre-peak trends has increased from around $4 \%$ before 2000 to around $7 \%$ since then. Housing downturns in the late 2000s occurred at the time of the global financial crisis and the euro area sovereign debt crisis. Severe downturns in various non-property sectors directly contributed to the GDP shortfall. Property price corrections can have a negative impact on the creditworthiness of countries and other issuers because they can reduce economic activity, dampen household wealth and consumption, and in some cases dampen revenues for local or national governments. Corrections can also raise the credit risk of housing loans by cutting the value of the collateral, while government sometimes adopt fiscal and monetary policy to mitigate the effect of lower house prices.

\subsection{Gross National Income Rate (GNI Rate)}

The housing market study conducted by Chen (Chen, 2007) found that gradual increase in income may capable to sustain the long-run trend in house prices. This finding indicates that income increment rate has strong positive impact towards housing price. Another similar study has been completed by Tsai and Peng (Tsai \& Peng, 2011). Their study focuses in determining the relationship between the housing price towards mortgage rate, income, economic growth rate, homeownership rate and inflation rate. The findings state that the income increment rate is most likely related to housing price increment.

\subsection{Basic Lending Rate (BLR); or Base Rate (BR)}

The Base Lending Rate (BLR) structure in Malaysia was replaced with a new Base Rate (BR) system effective at 2nd January 2015. The housing demand will increase if the lending rate is preferable. The increasing demand will positively influence the housing price (Barakova, 2003). According to International Monetary Fund research (IMF 2000), the credit cycles have matched the housing cycles in a number of countries. Home owners tend to focus on the interest rates changes because they have a direct impact on the housing price. The interest rate might also affect the capital availability and the investment demand. These capital flows will influence the supply and demand for property and hence, they will most probably impact the housing prices.

\section{The Methodology}

The methodology use in this study is exploratory study. The research aims are to determine the relationship that exists between the housing price and the economic variables such as gross domestic product rate, inflation rate, income increment rate, Bank interest rate and real property gain tax rate.

The developed hypotheses are as below: 
H1: The inflation rate (INF) has a positive influence on the housing price.

$\mathrm{H} 2$ : The gross domestic product rate (GDP) has a positive impact on the housing price.

H3: Gross National Income rate (GNI) is positively correlated with the housing price.

H4: Housing price Index (HPI) will be higher if Basic Lending Rate (BLR) is lower.

This study divided into two parts:

Part 1: Individual effect - To measure the relationship between housing price and economic factors individually using bivariate study.

Part 2: Interactive effect - To measure the interactive effect between housing price and economic factors using regression model.

The regression model can be built as below:

$$
H P I=I N F+G D P+G N I+B L R+E
$$

Where $\quad$ HPI $=$ Housing Price Index

$$
\begin{aligned}
& \text { INF = Inflation Rate } \\
& \text { GDP = Gross Domestic Product } \\
& \text { GNI = Gross National Income } \\
& \text { BLR = Basic Lending Rate } \\
& \text { E = Error }
\end{aligned}
$$

\subsection{The Sample}

The conceptual model as shown in Figure 3 is created to determine the relationship between housing price index

\begin{tabular}{|c|c|}
\hline Index & Secondary Data Source \\
\hline $\begin{array}{l}\text { Gross Domestic } \\
\text { Product Rate }\end{array}$ & Department of Statistic Malaysia \\
\hline Inflation Rate & Bank Negara Malaysia \\
\hline Basic Lending Rate & Bank Negara Malaysia \\
\hline $\begin{array}{l}\text { Gross National Income } \\
\text { Rate }\end{array}$ & Ministry of Finance Malaysia \\
\hline $\begin{array}{l}\text { House Price Index } \\
\text { Rate }\end{array}$ & $\begin{array}{l}\text { Valuation and Property Services } \\
\text { Department }\end{array}$ \\
\hline
\end{tabular}
and economic factors. Secondary data were obtained from the Department of Statistics of Malaysia, Bank Negara Malaysia, Ministry of Finance Malaysia, Valuation and Property Services Department. The economical indexes and their corresponding secondary data sources are listed at Figure 4.

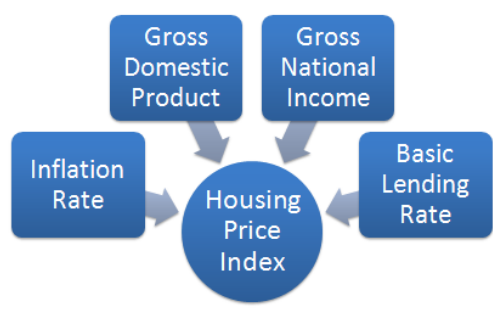

Figure 3. Conceptual model: housing price index and economic factors

Figure 4. Economical indexes and corresponding secondary data source

\subsection{Limitations}

To reflect the latest situation, the secondary data were collected from 2005 until 2014. As year 2014 has just 
ended few months ago, most of the collected secondary data for year 2014 are predicted values. This includes the HPI, GDP and GNI. The predicted values might have slight difference compared to the actual value especially when there are big swings in fourth quarter of year 2014. Nevertheless, the differences are foreseen to be minimal as we have a stable economy in fourth quarter.

The Penang Housing Price Index (HPI) is obtained from Valuation and Property Services Department. To have comprehensive correlation study, the HPI is being transformed into HPI rate as the HPI rate is not available from secondary source. The performed calculation is listed below. The calculated results are shown in Figure 5.

HPI rate $=($ Current HPI rate - Previous HPI rate $) /$ Previous HPI rate $\mathrm{x} 100 \%$

\begin{tabular}{|c|c|c|}
\hline Year & HPI & HPI Rate \\
\hline 2005 & 125 & NA \\
\hline 2006 & 125 & 0.00 \\
\hline 2007 & 130 & 4.00 \\
\hline 2008 & 140 & 7.69 \\
\hline 2009 & 140 & 0.00 \\
\hline 2010 & 150 & 7.14 \\
\hline 2011 & 160 & 6.67 \\
\hline 2012 & 170 & 6.25 \\
\hline 2013 & 185 & 8.82 \\
\hline
\end{tabular}

Figure 5. Calculated HPI rate based on HPI obtained from valuation and property services department

\subsection{Pilot Run}

Before performing the full data analysis, a pilot run was performed. Pilot run was conducted to check the sampling efficiency and the methodology effectiveness. Gross domestic product rate is selected for the pilot run.

Based on trend chart, GDP rate showed strong influence towards housing price. Bivariate Fit is selected to evaluate the statistical significance between these two variables. Bivariate Fit showed slight positive correlation with R2 of 0.26 . The calculated F-test is not statistically significant.

From the observation, we can conclude the relationship between the GDP rate and the housing price index. As we are capable to draw constructive recommendations from the analysis, the sampling plan is proven sufficient and the chosen methodology is useful to calculate the significant linearity between economical factors and housing price index. Following on the successful pilot run, the full data analysis was conducted.

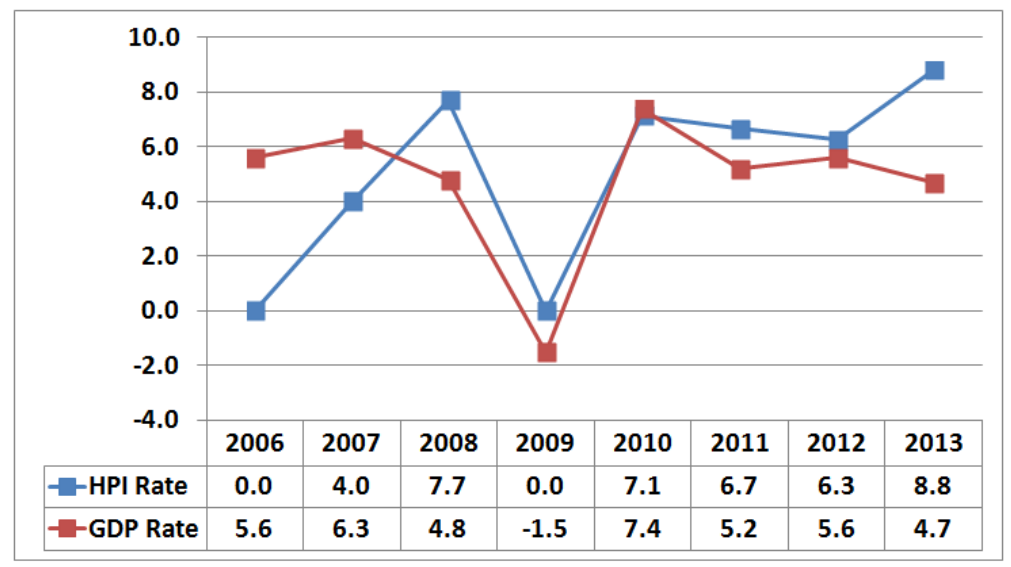

Figure 6. Housing price index rate and gross domestic product rate comparison 

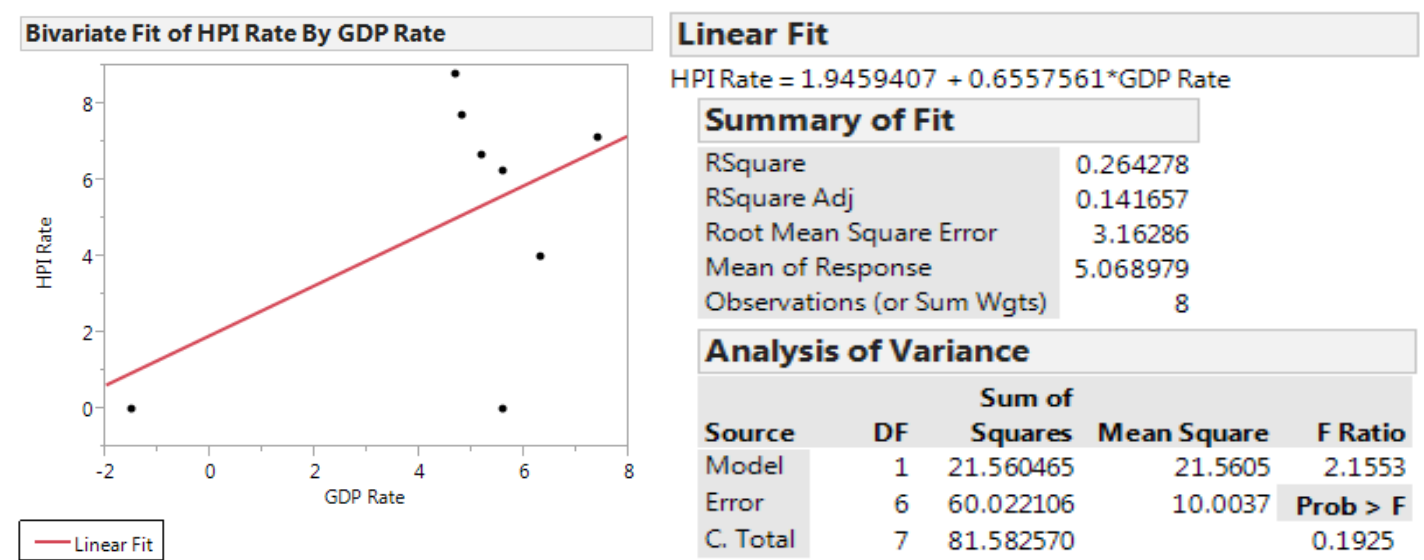

Figure 7. Bivariate fit study of HPI rate by GDP rate

\section{Data Analysis}

\subsection{Bivariate Fit Study on Individual Economic Effects Towards Housing Price}

4.1.1 House Pricing Index Rate vs. Gross Domestic Product Rate

Based on trend chart, GDP rate showed strong influence towards housing price. Bivariate Fit is selected to evaluate the statistical significance between these two variables. Bivariate Fit showed slight positive correlation with $\mathrm{R} 2$ of 0.26 . The calculated F-test is not statistically significant.

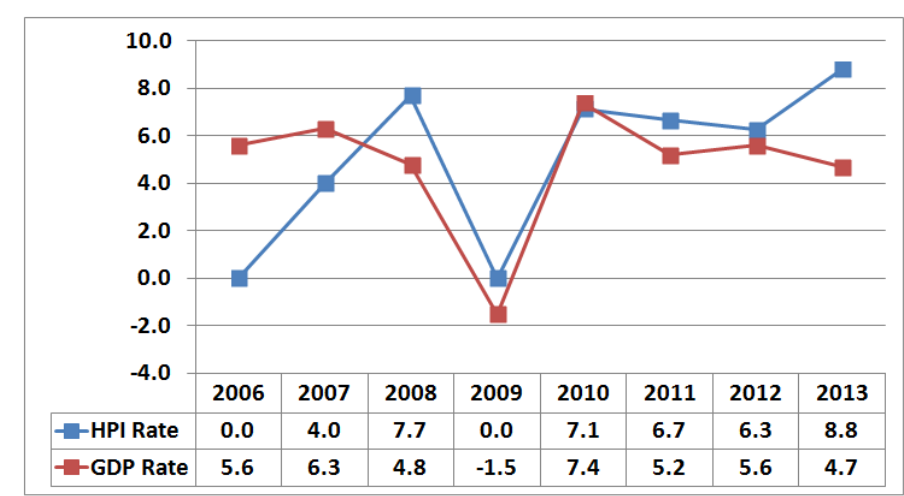

Figure 8. Housing price index rate and gross domestic product rate comparison

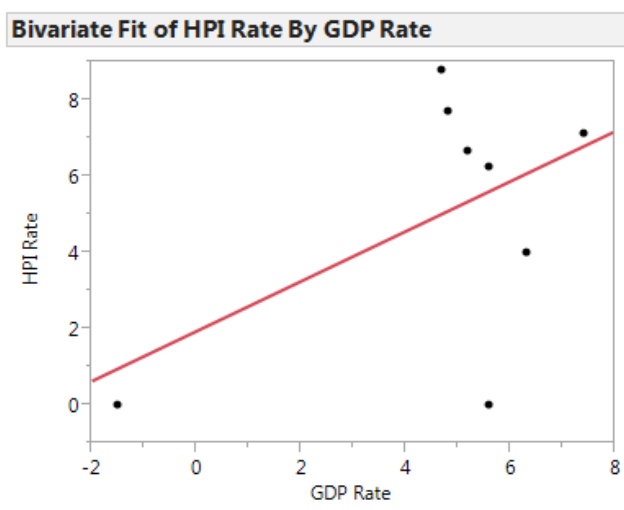

\begin{tabular}{|c|c|c|c|c|}
\hline \multicolumn{5}{|c|}{ Linear Fit } \\
\hline \multicolumn{5}{|c|}{ HPI Rate $=1.9459407+0.6557561^{\star}$ GDP Rate } \\
\hline \multicolumn{4}{|c|}{ Summary of Fit } & \\
\hline \multicolumn{3}{|c|}{ RSquare } & \multicolumn{2}{|l|}{0.264278} \\
\hline \multicolumn{3}{|c|}{ RSquare Adj } & \multicolumn{2}{|l|}{0.141657} \\
\hline \multicolumn{3}{|c|}{ Root Mean Square Error } & \multicolumn{2}{|l|}{3.16286} \\
\hline \multicolumn{3}{|c|}{ Mean of Response } & \multicolumn{2}{|l|}{5.068979} \\
\hline \multicolumn{3}{|c|}{ Observations (or Sum Wgts) } & \multicolumn{2}{|l|}{8} \\
\hline \multicolumn{5}{|c|}{ Analysis of Variance } \\
\hline \multicolumn{5}{|c|}{ Sum of } \\
\hline Model & 1 & 21.560465 & 21.5605 & 2.1553 \\
\hline Error & 6 & 60.022106 & 10.0037 & Prob $>F$ \\
\hline C. Total & 7 & 81.582570 & & 0.1925 \\
\hline
\end{tabular}

Figure 9. Bivariate fit study of HPI rate by GDP rate 


\subsubsection{House Pricing Index Rate vs. Inflation Rate}

Both the trend chart and the bivariate study showed no significant correlation between housing price and inflation rate. The analysis showed a weak F-value, which is 0.61 .

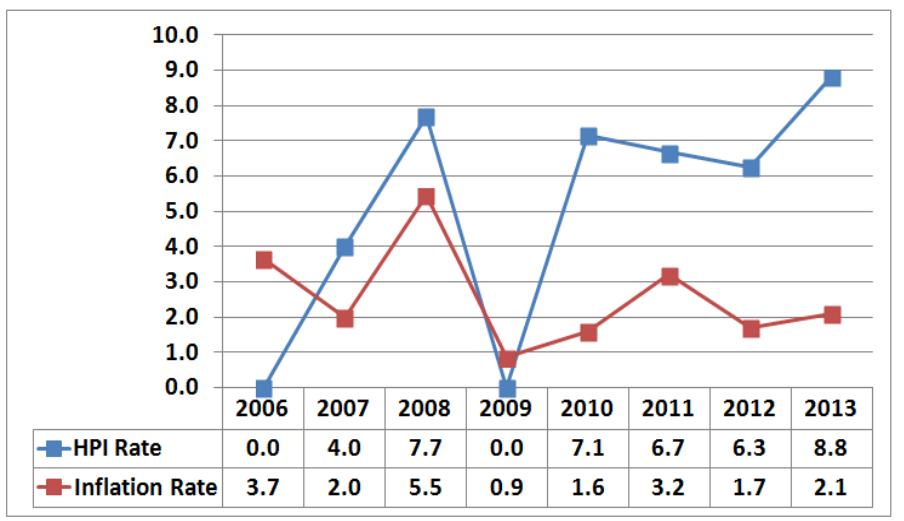

Figure 10. Housing price index rate and inflation rate comparison
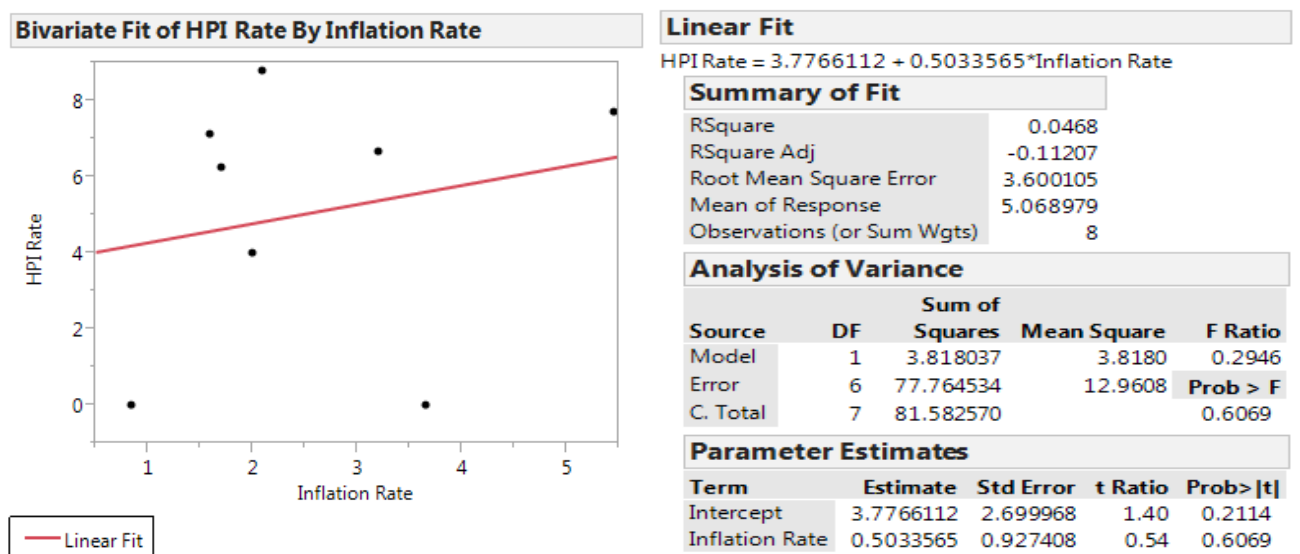

Figure 11. Bivariate fit study of HPI rate by inflation rate

\subsubsection{House Pricing Index Rate vs. Base Lending Rate}

Housing price showed significantly strong positive correlation with basic lending rate. The calculated F-value is 0.0493 which is statistically significant.

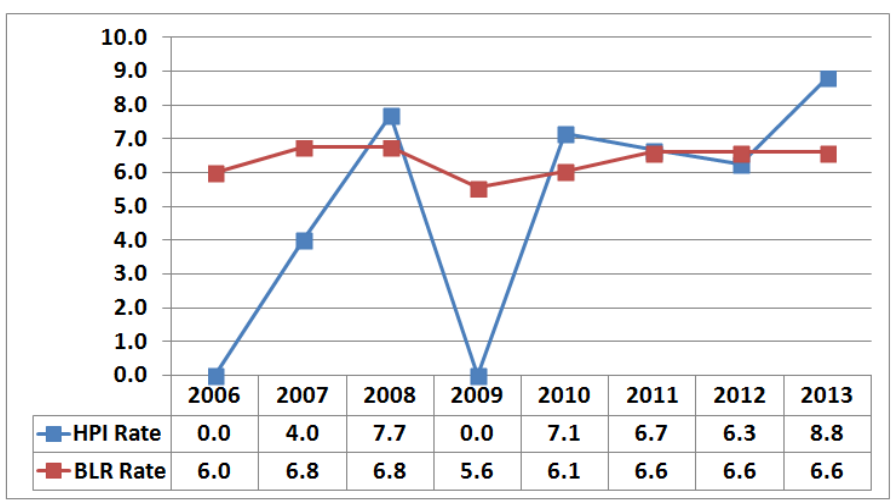

Figure 12. Housing price index rate and basic lending rate comparison 

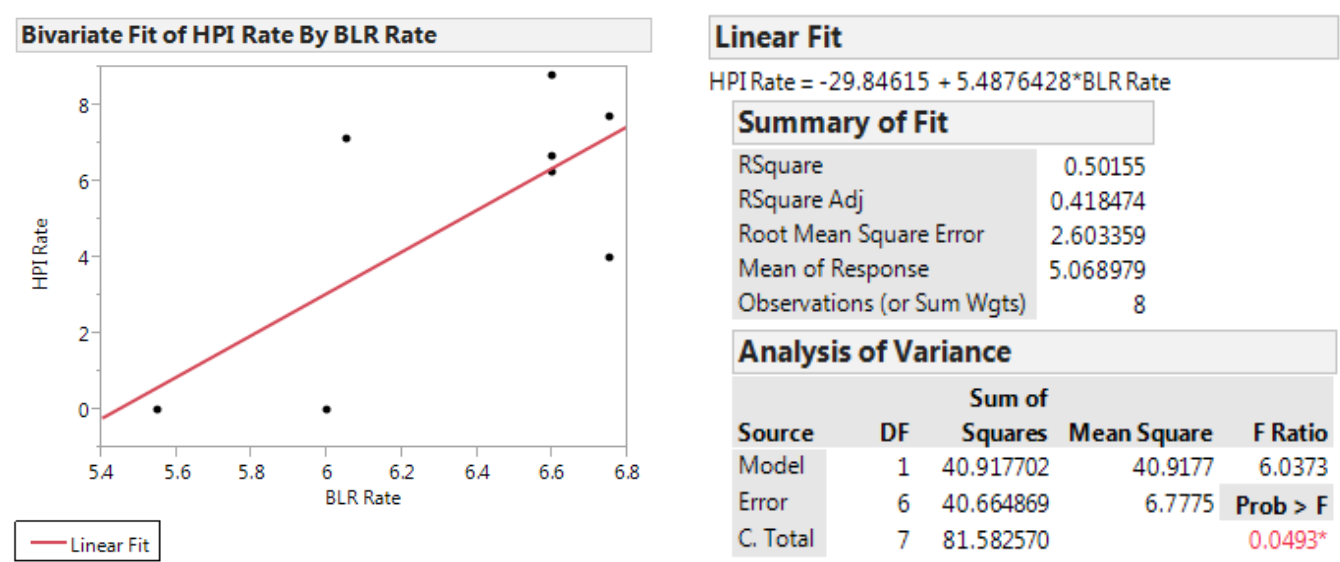

Figure 13. Bivariate fit study of HPI rate by BLR rate

\subsubsection{House Pricing Index Rate vs. Gross National Income Rate}

The trend chart showed slight correlation between housing price and gross national income rate. The bivariate fit study showed F-value of 0.32 which is not statistical significant. The study demonstrated weak positive housing price towards gross national income rate.

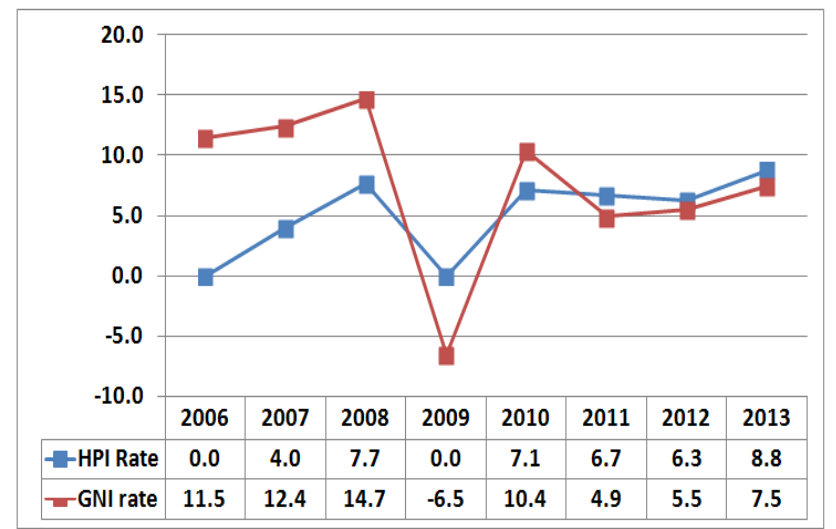

Figure 14. Housing price index rate and gross national income rate comparison

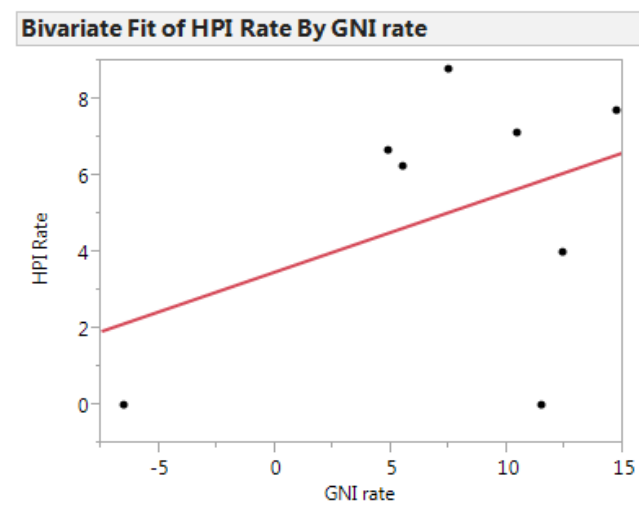

\begin{tabular}{|c|c|c|c|c|}
\hline \multicolumn{5}{|c|}{ Linear Fit } \\
\hline \multicolumn{5}{|c|}{ HPI Rate $=3.4990222+0.2079413^{*} \mathrm{GNI}$ rate } \\
\hline \multicolumn{5}{|c|}{ Summary of Fit } \\
\hline $\begin{array}{l}\text { RSquare } \\
\text { RSquare } \\
\text { Root Me } \\
\text { Mean of } \\
\text { Observa }\end{array}$ & $\begin{array}{l}\text { quar } \\
\text { pons } \\
\text { sor }\end{array}$ & Error & $\begin{array}{r}0.162713 \\
0.023165 \\
3.374118 \\
5.068979 \\
8\end{array}$ & \\
\hline \multicolumn{5}{|c|}{ Analysis of Variance } \\
\hline Source & DF & $\begin{array}{l}\text { Sum of } \\
\text { Squares }\end{array}$ & f & $\begin{array}{l}\text { F Ratio } \\
1.1660\end{array}$ \\
\hline Model & 1 & 13.274551 & $1 \quad 13.2746$ & 1.1660 \\
\hline Error & 6 & 68.308019 & 11.3847 & Prob $>F$ \\
\hline C. Total & 7 & 81.582570 & & 0.3217 \\
\hline
\end{tabular}

Figure 15. Bivariate fit study of HPI rate by GNI rate 
4.1.5 Summary of Bivariate Fit Study on Individual Economic Effects towards Housing Price

Figure 14 summarizes the Bivariate Fit Studies. The only economical factor which statistically correlated with housing price is BLR. Based on the F-value, GDP rate is the second strongest correlated factor and follow by gross national income rate. From the study, inflation rate is not correlated with housing price. The study showed that housing price main dominating economical factors is BLR.

All economical factors showed positive correlation towards housing price. This is contradicting to the initial hypothesis which predicted that the BLR will have negative impact towards housing price. The reasonable explanation for this observation is BLR might have laggard effect towards housing price. Housing price will probably trend lower a few years later after the BLR adjustment took place. Thus, the direct correlation from particular year is not seen. Furthermore, BLR increment might due to higher loan application which indicates higher housing demand. Higher housing demand will most probably contributed to higher housing price.

\begin{tabular}{|l|l|l|l|l|}
\hline Factors & Correlation & $\begin{array}{l}\text { Trend } \\
\text { Observations }\end{array}$ & F-Test & $\begin{array}{l}\text { Statistical } \\
\text { Significant }\end{array}$ \\
\hline GDPRate & Positive & Correlated & 0.193 & No \\
\hline Inflation Rate & Positive & Not correlated & 0.607 & No \\
\hline BLR & Positive & Correlated & 0.049 & Yes \\
\hline GNI Rate & Positive & Correlated & 0.322 & No \\
\hline
\end{tabular}

Figure 16. Bivariate fit study summary

Economic factors might have positive and negative influence among each other's. For example, GDP rate might influence the GNI rate and the inflation rate will impact the MLR. Regression model can be utilized to evaluate the interactive effects among economical factors. Figure 15 showed the regression model generated using JMP software.

\subsection{Regression Model to Measure the Interactive Effect between Housing Price and Economic Factors}

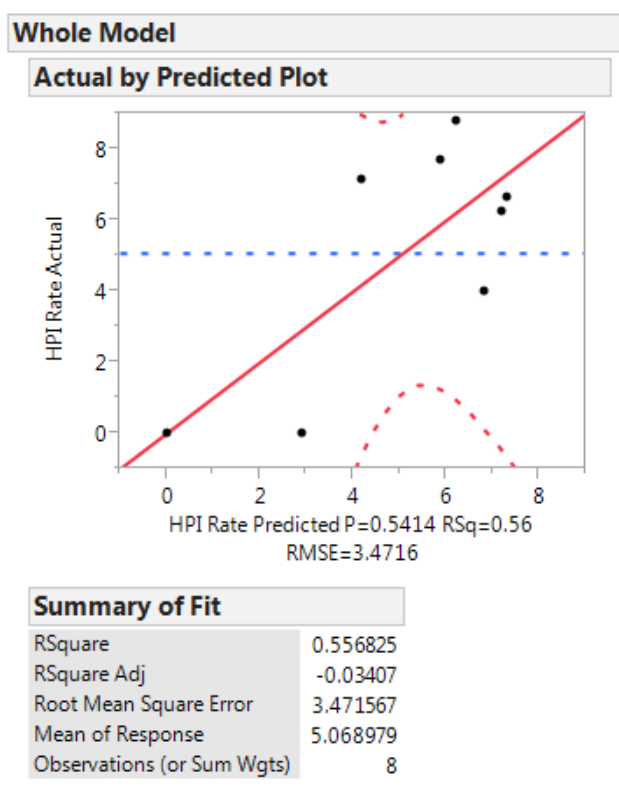

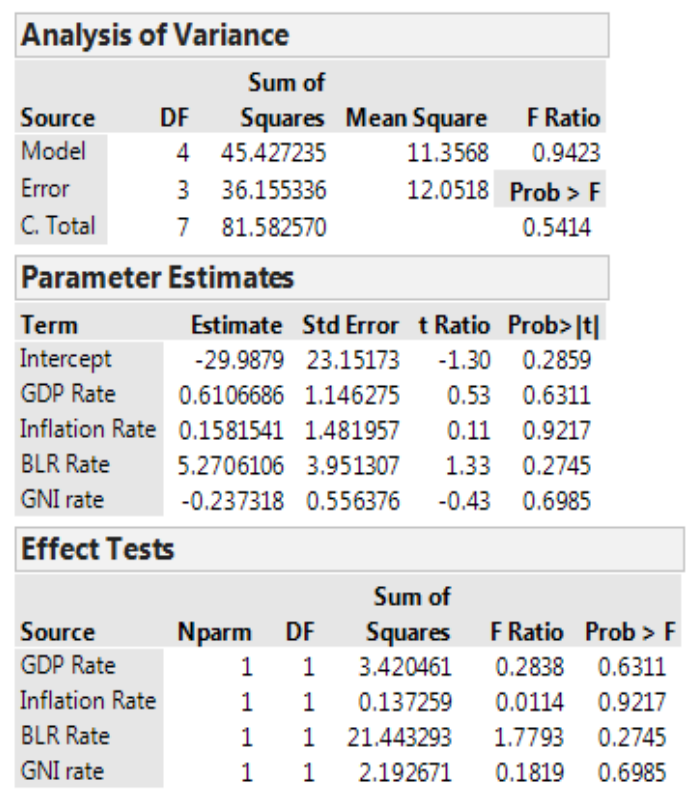

Figure 17. Regression model generated using JMP software 
Using the parameter estimates generated, the regression model is created as shown below.

$\mathrm{HPI}=0.61$ GDP Rate + 0.16 Inflation Rate + 5.27 BLR Rate -0.24 GNI rate -29.99

$\mathrm{R} 2=0.56$

Generated R2 showed significant correlation between housing price and the carefully selected four economical factors. Based on the F-value calculated, the regression analysis showed similar result with the bivariate fit analysis. The most significant economical factor is BLR, follow by GDP rate and GNI rate. Inflation rate has a very high F-value which indicates no correlation towards housing price.

From parameter estimates, BLR and GDP rate have positive influence towards housing price while GNI rate showed negative impact towards housing price. The negative correlation observed is not within initial expectation. The possible explanation is the higher housing price due to higher gross national income rate is being leveraged by other economical factors such as inflation rate and BLR. As the interest payable and currency depreciation is higher than the gross income increment, the GNI rate showed a negative influence towards the housing price.

\section{Conclusion and Recommendations}

In this research, secondary data are collected from Bank Negara Malaysia, Department of Statistic Malaysia, Ministry of Finance Malaysia and Valuation and Property Service Department. All the economical factors are on a yearly basis from 2007 to 2014 . The study was conducted to verify the relationship between the economical factors and housing price in Penang. Both the individual effects and the interactive effects are analyzed and reasonable explanations are given on the observations.

Based on Bivariate study, BLR showed positive and significant correlation towards housing price. GDP rate and GNI rate showed positive correlation with housing price. However, the correlation is not statistically significant. Inflation rate has the least influence towards housing price. Using the regression model, the selected economical factors were carefully examined. Similarly with the bivariate findings, BLR demonstrated the strongest correlation towards housing price, follow by GDP rate and GNI rate.

Positive correlation between GDP rate and housing price is expected and aligned the initially generated hypothesis. However, positive correlation between BLR and housing price is not within expectation. Literature review suggested that BLR should have negative influence towards housing price. The housing market study conducted by Chen (Chen, 2007) found that gradual increase in income may capable to sustain the long-run trend in house prices. The possible explanation on this unpredicted result is BLR might have laggard effect towards housing price. Housing price might probably trend lower only a few years later after the BLR adjustment took place.

Bivariate study showed positive correlation between housing price and GNI rate while regression model indicated a negative correlation. The possible explanation is the higher housing price due to higher gross national income rate is being leveraged by other economic factors such as inflation rate and BLR. As the interest payable and currency depreciation is higher than the gross income increment, the GNI rate showed a negative influence towards the housing price.

The regression model showed R2 of 0.56 which indicates that there are other variables which contribute to the housing price. In future studies, other type of factors might be included. This includes political factors, social factors, technology factors, legal factors and environmental factors. Applying the PESTEL analysis, the regression model generated is expected to reach $\mathrm{R} 2$ closer to 1.00 which indicates that definite correlation is achieved and all variables which contributed to the housing price changes are included.

\section{References}

Barakova, I., Bostic, R. W., Calem, P. S., \& Wachter, S. M. (2003). Does credit quality for homeownership. Journal of Housing Economics, 318-336. http://dx.doi.org/10.1016/j.jhe.2003.09.002

Chen, M. C., Tsai, I. C., \& Chang, C. O. (2007). House prices and household income: Do they move apart? Evidence from Taiwan. Journal of Public Economics, 243-256. http://dx.doi.org/10.1016/j.habitatint.2007.02.005

Cho, D., \& Seugryul, M. (2006). Dynamic Relationship Between Housing Values and Interest Rats in the Korean Housing Market. Journal of Real Estate Finance and Economics, 32(2), 169-184. http://dx.doi.org/10.1007/s11146-006-6013-6

Feldstein, M. (1980). Inflation, tax rules, and the prices of land and gold. Journal of Public Economics, 309-317. 
http://dx.doi.org/10.1016/0047-2727(80)90029-8

Heng, Y. K. (2013). Penang: Real Estate Market. MPI Property Quotient, 7. Malaysia Property Incorporated Publication.

IMF. (2000). Word Economic Outlook, May 2000. Washington D.C: IMF.

Ley, D., \& Judith, T. (2010). Immigration, Globalization and House Prices in Canada's Gateway Cities. Journal of Housing Studies, 199-223.

Mary, G. (n. d.). Demand Media, the Effect of Inflation on Housing Prices. Retrieved from http://homeguides.sfgate.com/effect-inflation-housing-prices-2161.html

Piazzesi, M., \& Schneider, M. (2009). Momentum Traders in the Housing Market: Survey Evidence and a Search Model. American Economic Review: Papers \& Proceedings, 406-411. http://dx.doi.org/10.1257/aer.99.2.406

Ray, M. V. (n. d.). Pepperdine University: the housing bubble and GDP; A correlational Perspective. Journal of Case Research in Business and Economics. Retrieved from http://www.aabri.com/manuscripts/10490.pdf

Tan, Y. K. (2011). An Hedonic Model for House Prices in Malaysia. International Real Estate Society Conference, 12-15.

Trey, G. (2015). Here's how housing market corrections drag on GDP. Retrieved from http://www.housingwire.com/articles/33587-heres-how-housing-market-corrections-drag-on-gdp

Tsai, I. C., \& Peng, C. W. (2011). Bubbles in the Taiwan housing market: The determinants and effects. Journal of Habitat International, 379-390.

Zhu, H. (2006). The Structure of Housing Finance Markets and House Prices in Asia. Bank for International Settlements.

\section{Copyrights}

Copyright for this article is retained by the author(s), with first publication rights granted to the journal.

This is an open-access article distributed under the terms and conditions of the Creative Commons Attribution license (http://creativecommons.org/licenses/by/3.0/). 